MATERIAŁY ŹRÓDŁOWE

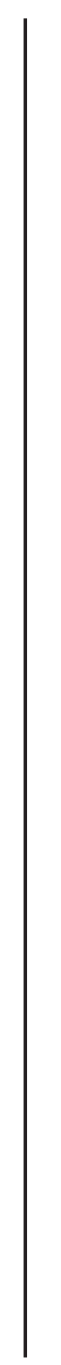




\title{
Danuta Quirini-PopŁaWska
}

Uniwersytet Jagielloński

\section{Eugeniusz Quirini de Saalbrïck, Kartki z działalności żołnierzy polskich we Francji i ich ewakuacja do Wielkiej Brytanii w czerwcu 1940 r.}

\begin{abstract}
Memoirs of Eugeniusz Quirini de Saalbrück illuminate his activity as a cultural and educational clerk in 1940 at the Officers' Rallying Station in Camp de Carpiagne, the unexpected surrender of France was a great tragedy, Polish soldiers wanted to fight and refused to lay down their arms. The Polish government-in-exile decided to continue the fight with English allies and to evacuate soldiers, including those from Camp de Carpiagne to the port of Saint Jean de Luz, from where they reached Plymouth on ship „Batory”.
\end{abstract}

\section{Wprowadzenie}

Autor niniejszego wspomnienia Eugeniusz Quirini de Saalbrück (ur. 29 lipca 1891 - zm. 27 maja 1978), ps. „Włoch”, ppłk dypl. Wojska Polskiego, ${ }^{1}$ słuchacz Wyższej Szkoły Realnej we Lwowie, Wydziału Budownictwa Dróg i Mostów Politechniki Lwowskiej, Wyższej Szkoły Wojennej (WSWoj) oraz Uniwersytetu w Cambridge, członek tajnej organizacji Armia Polska we Lwowie (1911), Drużyn Strzeleckich, wraz z IV Drużyną Strzelecką z Kleparowa, której był organizatorem i instruktorem 3 sierpnia $1914 \mathrm{r}$.

Centralne Archiwum Wojskowe Wojskowego Biura Historycznego (dalej: CAW-WBH), Kolekcja Teczek Akt Personalnych (dalej: TAP), 1570/75/758, Potwierdzony za zgodność odpis Aktu Mianowania do stopnia podpułkownika, Londyn, 1 VII 1945 r., 3. 
wstąpił w Krakowie do Legionów Polskich. Został skierowany do 3 Pułku Piechoty (pp) II Brygady Legionów Polskich i wziął udział we wszystkich jej kampaniach: karpackiej, besarabskiej, bukowińskiej i wołyńskiej. ${ }^{2}$ Po wybuchu wojny polsko-bolszewickiej od marca 1919 r. walczył na Polesiu wraz z 34 pp, a następnie mianowany został szefem sztabu Grupy Operacyjnej XVIII Brygady Piechoty płk. Jerzego Narbutta-Łuczyńskiego, potem szefem sekcji w Oddziale I (Operacyjnym) Naczelnego Dowództwa Wojska Polskiego. Do przewrotu majowego odniósł się negatywnie, co walnie przyczyniło się do załamania jego kariery wojskowej. Po nominacji na majora w 1924 r. do wybuchu II wojny światowej nie awansował. ${ }^{3} \mathrm{~W}$ latach 1928-1932 pełnił obowiązki szefa Wojskowego Instytutu Naukowo-Wydawniczego, a w 1934 r. przejął funkcję zastępcy szefa tej instytucji. Był redaktorem czasopisma Bellona (od 1928 r.), a w 1930 r. stworzył i redagował tygodnik Wiarus, publikował albumy, opracowania i wspomnienia dotyczące tematyki legionowej oraz wyszkolenia wojskowego, m.in. Prawa i obowiązk podoficera (Warszawa 1920); Stanowisko podoficera $w$ Wojsku Polskim (Warszawa 1920); Bogusław Szul podpułkownik S.G. Próba Życiorysu (Warszawa 1933); wraz z Wacławem Lipińskim opracował Album Legionów polskich (Warszawa 1933); a wraz ze Stanisławem Librewskim, Ilustrowana Kronikę Legionów Polskich 1914-1918; redaktor Księgi chwały piechoty (Warszawa 1937-1939). Tłumaczył też dzieła zagranicznych autorów dotyczące ważnych wydarzeń historycznych. Przełożył z francuskiego pracę Philippa Pétaina, Bitwa pod Verdun (Warszawa 1931) oraz m.in. Dowodzenie $i$ walka broni połaczonych, część II (Warszawa 1926) (z niemieckiego), artykuły omawiające stosowane na Zachodzie najnowocześniejsze taktyki, w tym taktykę broni połączonych, oraz sztukę dowodzenia. ${ }^{4}$

Zmobilizowany 1 września 1939 r.; wziął udział w kampanii polskiej 1939 r. i obronie Warszawy. Odkomenderowany został do dyspozycji szefa Biura Propagandy Naczelnego Wodza ppłk Romana Umiastowskiego, ${ }^{5}$ który przekazał mu również tzw. referat niemiecki, czyli rozkaz sporządzania aktualnych komunikatów z frontu niemieckiego. ${ }^{6}$ Jak wynika z zachowanego

\footnotetext{
2 Henryk Korczyk, „Quirini de Saalbrück Eugeniusz," Polski Słownik Biograficzny (PSB) 29, (1986): 532.

3 CAW-WBH, TAP, 1570/75/758, Przebieg służby Eugeniusza Quirini, b.m., b.d., b.p.

4 Ibid. Oraz wyciągi z rozkazów wewnętrznych m.in. Dowództwa Okręgu Korpusu II w Lublinie oraz listy kwalifikacyjne od 1924 do 1939 r. Informacje zaczerpnięte z pozostawionych rękopiśmiennych „Wspomnień” Quiriniego obejmujących lata 1891-1947.

5 Archiwum Prywatne Rodziny Quirini, Zaświadczenie Szefa Propagandy Naczelnego Wodza ppłk. dypl. Romana Umiastowskiego o przydzieleniu do biura Szefa Propagandy NW l.dz 27/39, [Warszawa], 5 IX 1939 r., b.p.

6 Informacje zapisane ręcznie przez Eugeniusza Quiriniego, w których czytamy: „otrzymałem referat niemiecki, miałem składać komunikaty na temat sytuacji Niemiec. Biuro
} 
przez autora wspomnienia „Kalendarzyka Terminowego na rok 1939”, jego wyjazd $\mathrm{z}$ Warszawy nastąpił 8 września o godz. $2 \mathrm{w}$ nocy i przez Łuków i Międzyrzec Podlaski (zatrzymał się na nocleg w Małaszewiczach), Brześć nad Bugiem dotarł 10 września do Włodawy i Chełma, gdzie zanocował, następnie przez Krasnystaw, Zamość, Tomaszów, Krystynopol, Radziechów i Kamionkę (12 września) dotarł do Lwowa. ${ }^{7}$ Wyjazd z miasta nastąpił o godz. 1 w nocy, następnie przez Złoczów (13 września), Brody (zatrzymał się we wsi Drobna na nocleg) oraz kolejno przez Łuck, Dubno, Krzemieniec, Zbaraż, Tarnopol, Czortków dojechał do Horodenki, aby w sobotę 16 września stanąć w Kołomyi i Kossowie, gdzie zatrzymał się na nocleg (17 września). W poniedziałek 18 września wraz z całą kolumną i z rządem przekroczył granicę w Kutach nad Czeremoszem oraz zanocował we wsi Granka, gdzie było przejście i punkt kontrolny. Kolejny nocleg wypadł w Storożyńcu, następnie w Radautzu (dziś Rădăuți), dalej dwie noce spędził w Bacău oraz od soboty 23 września przebywał przez trzy dni w Focşani, w Sărat i Buzău, aby 28 września stanąć w Ploeszti, gdzie tegoż dnia dotarła doń wiadomość o upadku Warszawy. Kolejne cztery dni spędził w Bukareszcie, gdzie 30 września zgłosił się w polskim konsulacie jako uciekinier z Polski, przedstawiając paszport nr III/5250. ${ }^{8}$ Tutaj 2 października dowiedział się o wejściu Niemców do Warszawy, następnie ponownie pojechał do Ploeszti. Kolejne 6 dni spędził w Czerniowcach. We wtorek 10 października wraz z wieloma Polakami został internowany i zatrzymany w obozie w $\mathrm{Bu}-$ kareszcie do 26 grudnia 1939 r., spędzając na obczyźnie pierwsze samotne święta Bożego Narodzenia. Następnie ruszył koleją przez Jugosławię i Zagrzeb do granicy włoskiej, dalej już na terenie Włoch m.in. przez Postumię (dziś Postojna), Triest do Wenecji. ${ }^{9}$ Po załatwieniu wszystkich formalno-

znajdowało się w stadium organizacji. Komunikaty były wygłaszane przez radio przez ppłk. dypl. Umiastowskiego. Układałem je na podstawie informacji Oddziału II, podsłuchu radiowego, któryśmy otrzymywali w dużej ilości oraz prasy. Raz byłem na stacji zbornej, gdy przyprowadzono jeńców niemieckich, rozmawiałem z nimi i fotografowaliśmy ich do prasy, nazwiska jeńców podał szef przez radio. Po 6 września przestaliśmy [podawać] jakiekolwiek informacje, a [o] 9 rano wyjechaliśmy do Brześcia nad Bugiem, gdzie zgłosiliśmy się do Naczelnego Dowództwa".

7 We Lwowie widział się ze swym młodszym bratem Emanuelem (ur. 1895 - zm. 1940), mjr. żandarmerii Wojska Polskiego, który ze zdiagnozowanym zapaleniem płuc postanowił pozostać w szpitalu. Wedle informacji z telegramu otrzymanego 20 września w Bukareszcie, a wysłanego ze Lwowa, Emanuel został aresztowany przez Sowietów i wywieziony do Gorodoka koło Kijowa oraz umieszczony w obozie jenieckim w miejscowym monastyrze. Zginął w Kozielsku.

8 Archiwum Prywatne Rodziny Quirini, Dokument nr 562/5681 z 30 IX 1939 r. wydany przez Konsulat Rzeczypospolitej Polskiej w Bukareszcie, b.p.

9 Archiwum Prywatne Rodziny Quirini, Ferrovie dello Stato, Biglietto Speciale nr 08704, Treno da Postumia, Trieste a Venezia. Nie znamy okoliczności, w jakich Eugeniusz Quirini 


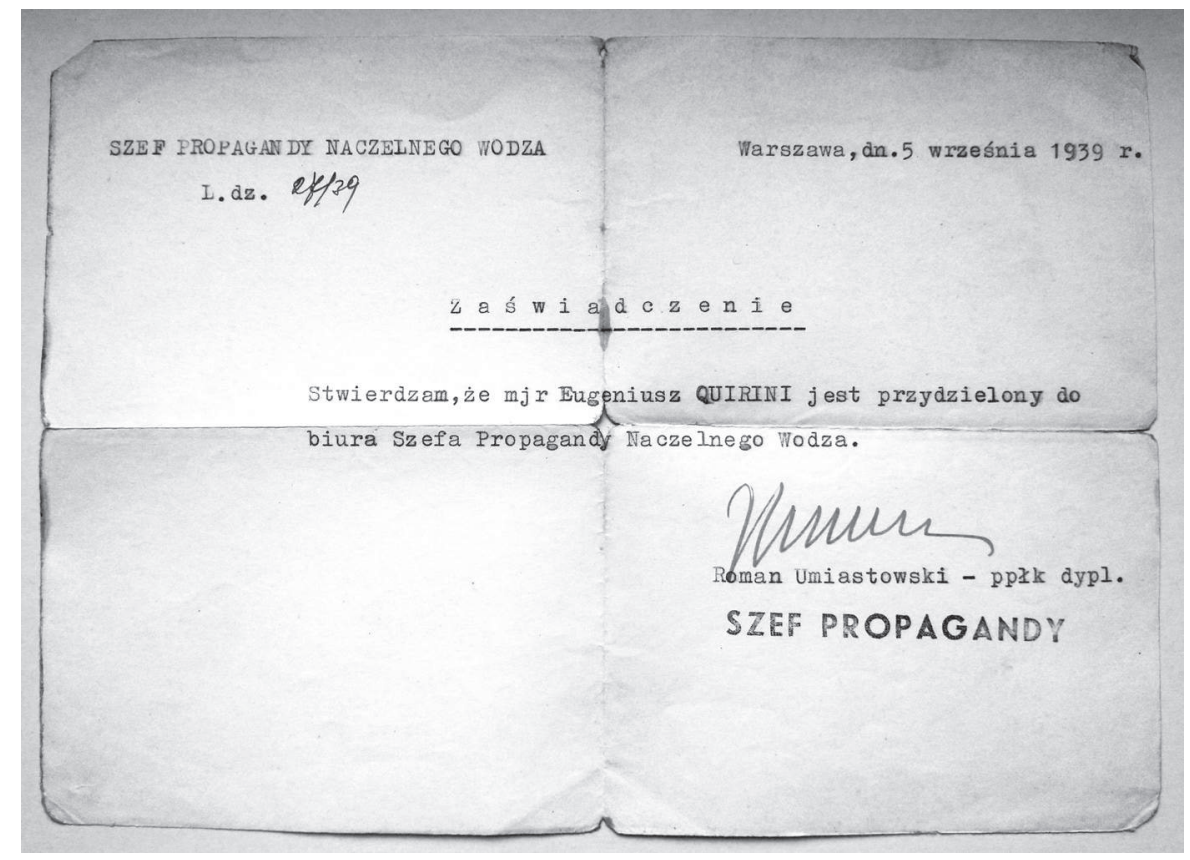

Zaświadczenie szefa propagandy Naczelnego Wodza ppłk. dypl. Romana Umiastowskiego o przydzieleniu do Biura Szefa Propagandy NW 1.dz 27/39.

Źródło: Archiwum Prywatne Rodziny Quirini

ści przejechał przez północne Włochy pociągiem, aby 31 grudnia $1939 \mathrm{r}$. o godz. 13 dotrzeć do Paryża. 1 stycznia 1940 r. zameldował się i został przyjęty na Stacji Zbornej dla Żołnierzy Polskich (Centre d'Hébergement pour les Militaires Polonais à Paris) w koszarach Bessieres w Paryżu. Tu napływający polscy żołnierze przechodzili weryfikację, otrzymywali służbowe przydziały oraz wyznaczani byli na stanowiska. ${ }^{10}$

W początkach 1940 r. na szczeblu MSWojsk. utworzono Wydział Propagandy i Oświaty składający się z dwóch referatów, który podlegał bezpośrednio pierwszemu wiceministrowi. Szefem wydziału został ppłk Janusz Sopoćko ${ }^{11}$. Wydział składał się $\mathrm{z}$ dwóch referatów, kierownikiem referatu

opuścił obóz internowania. W kalendarzyku bohater zanotował tylko informację o złożeniu paszportu na wyjazd i wyjeździe z Bukaresztu.

10 Maciej Szczurowski, „Geneza formowania Armii Polskiej we Francji 1939-1940,” Piotrkowskie Zeszyty Historyczne 4, (2002): 122; Archiwum Prywatne Rodziny Quirini, Certificat nr 3468 potwierdzający zameldowanie się i przyjęcie w Stacji Zbornej dla Żołnierzy Polskich w Paryżu, Paryż, 1 I 1940 r., b.p.

11 Janusz Sopoćko (ur. 1895 - zm. po 1968) - absolwent Pawłowskiej Szkoły Wojskowej w Petersburgu. Podczas I wojny światowej walczył w armii rosyjskiej, potem w formacjach 
propagandy został mjr dypl. Edward Ligocki ${ }^{12}$, zaś kierownikiem referatu oświaty mjr Eugeniusz Quirini. ${ }^{13}$ Już 19 marca 1940 r. rozkazem (nr 104/ Prop. i Ośw./40) szefa Wydziału Propagandy i Oświaty MSWojsk. ppłk. dypl. Sopoćko Quirini otrzymał zezwolenie na pracę w biurze wydziału poza normalnymi godzinami służbowymi (w myśl. pkt. 2 Rozk. Wewn. MSWojsk. nr 7) ${ }^{14} \mathrm{Na}$ tym stanowisku pracował do kwietnia 1940 r. Wówczas otrzymał przydział służbowy do Stacji Zbornej Oficerów w Camp de Carpiagne koło Marsylii, gdzie do 18 czerwca 1940 r. pełnił funkcję referenta kulturalno-oświatowego. Jak wspomina Witold Biegański: „referat oświaty, zatrudniający ponad 30 oficerów, opracowywał programy wychowania obywatelskiego, nauki języka polskiego i francuskiego oraz czuwał nad ich realizacją. Dobierał lektorów, analizował nastroje panujące wśród żołnierzy, kierował pracą kulturalno-oświatową oraz przede wszystkim szkolił oficerów oświatowych". ${ }^{15}$ To obóz w Camp de Carpiagne dostarczał oficerów oświatowych dywizjom i obozom. ${ }^{16}$ Po ewakuacji z Francji i dotarciu do Anglii Eugeniusz Quirini służył jako oficer propagandy i oświaty w Szkolnej

kontrrewolucyjnych na Syberii i w Chinach. Ewakuował się drogą morską w 1919 r. do Polski, uczestniczył w wojnie polsko-bolszewickiej w 1 Pułku Strzelców Wielkopolskich. Absolwent WSWoj, w latach trzydziestych XX w. mianowany kpt. dypl. oraz ppłk. dypl. Służył w Sztabie Głównym WP. Po zajęciu Polski przez Niemców przeszedł przez Węgry do Francji. W kwietniu 1940 r. wstąpił do 1 Dywizji Grenadierów, a po kapitulacji Francji w czerwcu został internowany w Szwajcarii. Pozostał na emigracji, osiedlił się w Szwajcarii i tam zmarł; Witold Biegański, Wojsko Polskie we Francji 1939-1940 (Warszawa: Wyd. Ministerstwa Obrony Narodowej, 1967), 183; Biegański, Zaczęło się w Coëtquitan: z dziejów polskich jednostek regularnych we Francji (Warszawa: Wyd. Ministerstwa Obrony Narodowej, 1977), 103-123.

12 Edward Ligocki (ur. 1887 - zm. 1966 w Warszawie) - pisarz, dyplomata, mjr dypl. WP, po klęsce 1939 r. we Francji, a po jej kapitulacji ewakuował się do Wielkiej Brytanii, następnie oddelegowany do Szkocji. W 1941 r. mianowany oficerem oświatowym z siedzibą w Edynburgu do łączności z władzami polskimi na obczyźnie; Zofia Bilek-Dąbrowska, „Ligocki Edward," PSB 17, (1972): 323-325.

13 Biegański, Zaczęło się, 97; Biegański, Wojsko, 183.

14 Archiwum Prywatne Rodziny Quirini, Rozkaz nr 104/Prop. i Ośw./40 płk. dypl. Janusza Sopoćko, m.p., 19 III 1940 r., b.p. W kalendarzyku Agenda 1940 r. zachował się regulamin obowiązujący polskich żołnierzy-pracowników MSWojsk.: pobudka o 6:30, śniadanie do 8:15, zajęcia od 14 do 17, modlitwa o godz. 21:45. Pod datą 26 lutego zanotował: „pierwsze strzały nad Paryżem o godz. 21:15".

15 Biegański, Zaczęło się, 97, 98.

16 W notatkach przechowywanych w Archiwum Prywatnym Rodziny Quirini odnaleziono informacje, że z Eugeniuszem Quirinim współpracowali we Francji m.in.: kpt. Jerzy Marian Ciepielowski (ur. 1899 - zm. 1969) - podczas wojny awansował do stopnia mjr. Był jednym z 76 polskich oficerów, których komunistyczna władza w Polsce pozbawiła 26 IX 1946 r. polskiego obywatelstwa. Nazwiska pozostałych wymienionych tu polskich oficerów: kpt. Józef Stojek; ks. kpt. Lamelski, ppor. Bunsch; kpt. Tarło-Maziński; ppor. Jedlicki. Zob. też Biegański, Wojsko, 183-184; Biegański, Zaczęło się, 97-98. 


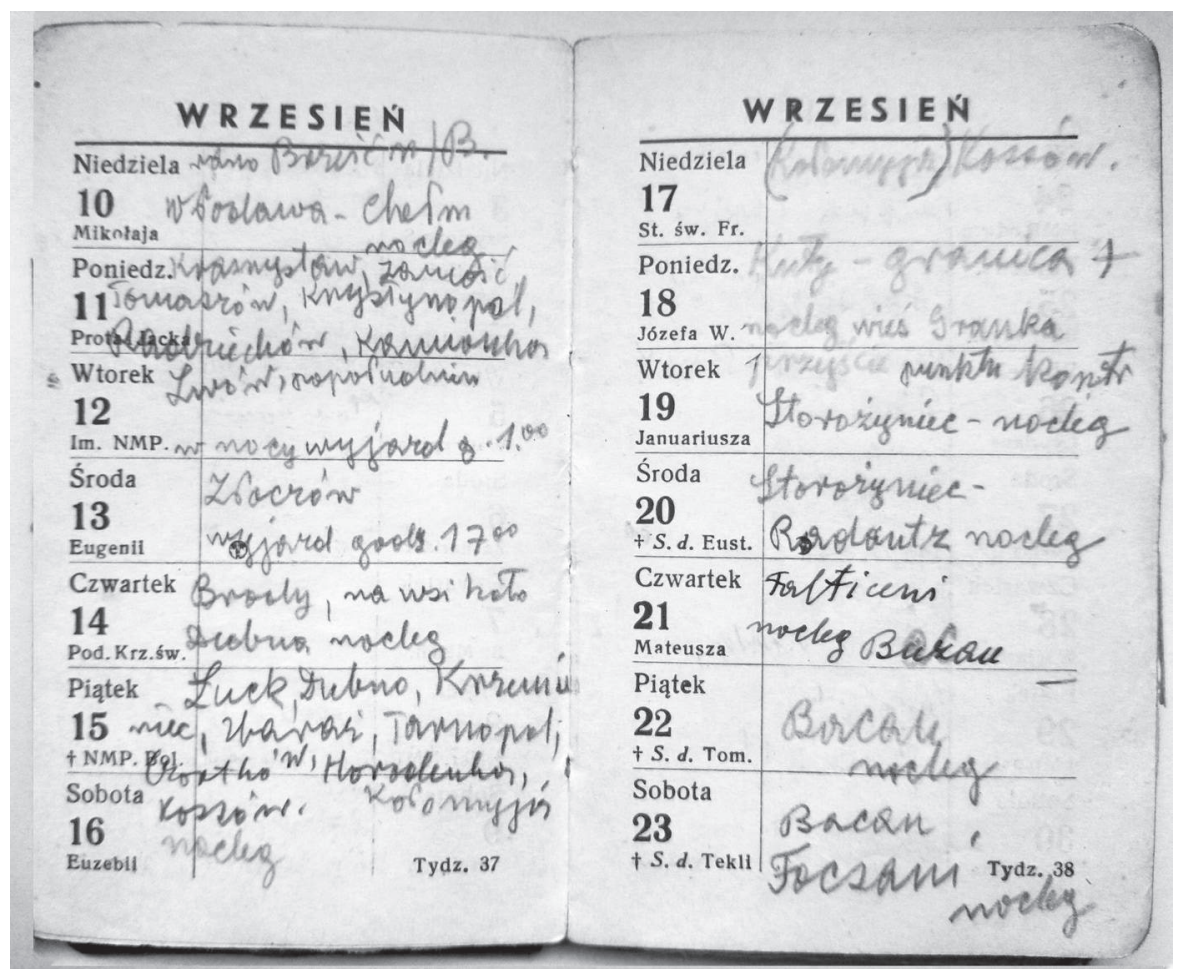

Kalendarzyk na rok 1939 z zapiskami Eugeniusza Quiriniego. Źródło: Archiwum Prywatne Rodziny Quirini

Brygadzie Kadrowej (od 23 czerwca 1940 do 1 stycznia 1942 r.). Na podstawie rozkazów gen. dyw. Mariana Kukiela z 24 i 29 sierpnia 1940 r. Quiriniego mianowano kierownikiem Samodzielnego Referatu Propagandy i Oświaty w Sztabie Dowództwa Obozów i Oddziałów Wojska Polskiego w Szkocji, początkowo w obozie oficerów w Peebles. W połowie października 1940 r. został odkomenderowany w charakterze referenta do spraw kulturalno-oświatowych do obozu Kirkcaldy, gdzie pozostał do 1942 r. ${ }^{17}$ Od 20 kwietnia 1942 r. do 16 lipca 1943 r. pracował jako ślusarz w fabryce maszyn okrętowych w Glasgow. 17 czerwca 1943 r. został powołany ponownie do służby czynnej i przydzielony do Polskiej Misji Wojskowej przy Naczelnym Dowództwie Alianckich Sił Ekspedycyjnych. W ramach tej służby pełnił swoje obowiązki przy 1 Amerykańskiej Dywizji Piechoty, potem skierowano go do Biura Opieki nad Żołnierzem. W kwietniu 1945 r. znalazł się w Biurze Historycznym 2 Korpusu Polskiego we Włoszech, następnie

17 Danuta Quirini-Popławska, „[Eugeniusz Quirini de Saalbruck], Kirkcaldy. Polska gwiazdka w Szkocji w 1940 r." Zeszyty Naukowe UJ, Prace Historyczne 49, z. 3 (2021): 623639, http://dx.doi.org/10.4467/20844069PH.21.040.14016. 
powrócił do Anglii. Chęć powrotu do kraju zgłosił w kwietniu 1947 r., gdzie przybył 25 października 1947 r. i osiadł w Krynicy Zdroju. Pracował jako referent w Funduszu Wczasów Pracowniczych, następnie nauczał j. angielskiego w liceum ogólnokształcącym, potem był kierownikiem planowania w Powiatowej Spółdzielni Spożywców w Krynicy. W 1958 r. przeszedł na emeryturę. ${ }^{18}$ Zmarł 27 maja 1978 r. w Krynicy Zdroju. Powyższy opis, zrekonstruowany na podstawie zamieszczonego $\mathrm{w}$ teczce akt personalnych przebiegu służby, jest niepełny i nie oddaje losu, jaki spotkał autora prezentowanego tekstu źródłowego po powrocie do Polski. W Krynicy Zdroju Quirini zamieszkał w wyniku nakazu osiedlenia, był inwigilowany w latach 1948-1955, ${ }^{19}$ utrudniano mu zdobycie „odpowiedniej pracy”, a także szykanowano i nie pozwalano publikować. Więcej o losach powojennych ppłk. dypl. Eugeniusza Quiriniego autorka planuje napisać w oddzielnym opracowaniu.

Prezentowane źródło opisuje działalność mjr. dypl. Quiriniego w trakcie jego służby w Stacji Zbornej Oficerów w Camp de Carpiagne oraz ewakuację tej placówki do Anglii. Realia działalności władz i wojska we Francji określiły zasady zawartej 9 września 1939 r. umowy wojskowej, podpisanej przez premiera i ministra obrony narodowej Francji Edouarda Daladiera oraz ambasadora Polski w Paryżu Juliusza Łukasiewicza, a także protokołu wykonawczego z 21 września tr. w sprawie utworzenia na terenie Francji jednej polskiej dywizji. Równocześnie Francuzi przekazali Polakom stary obóz wojskowy znajdujący się w Coëtquidan w Bretanii. ${ }^{20}$ Po ukonstytuowaniu się polskich władz na uchodźstwie 28 września 1939 r. gen. dyw. Władysław Sikorski został Wodzem Naczelnym Polskich Sił Zbrojnych (PSZ) oraz otrzymał tekę ministra spraw wojskowych, a 30 września został mianowany przez prezydenta Władysława Raczkiewicza na stanowisko premiera z misją utworzenia Rządu Jedności i Obrony Narodowej na uchodźstwie. W Ministerstwie Spraw Wojskowych (MSWojsk.) powołano dwóch wiceministrów: gen. Mariana Kukiela oraz płk. Izydora Modelskiego. 4 stycznia 1940 r. Sikorski i Daladier podpisali nową umowę wojskową zawierającą podstawowe akty prawne przymierza polsko-francuskiego. ${ }^{21}$ Do czerwca

18 CAW-WBH, TAP, 1570/75/758, Przebieg służby Eugeniusza Quirini, b.m., b.d., b.p.

19 Archiwum Instytutu Pamięci Narodowej w Krakowie, Wojewódzki Urząd Spraw Wewnętrznych w Krakowie [1945] 1983-1990, 010/3178, Sprawa ewidencyjno-obserwacyjna dot. Eugeniusz Quirini, imię ojca: Marian, ur. 29-07-1891 r. Kontrola operacyjna byłego dyplomowanego oficera WP sprzed 1939 r., oficera 2 Korpusu Polskiego gen. Władysława Andersa w stopniu majora.

20 Biegański, Wojsko, 59, 61-63; Biegański, Zaczęło się, 38-41.

${ }_{21}$ Biegański, Wojsko, 65-66, 69-71, 74; Józef Smoliński, Polskie Sity Zbrojne na Zachodzie 1939-1945 (Warszawa: Egros, 1997), 21-28; Monika Bielak, „Ewakuacja żołnierzy polskich z Francji do Wielkiej Brytanii i Afryki Północnej w latach 1940-1941," w Letnia Szkoła Historii Najnowszej 2008: Referaty, red. Bielak i Łukasz Kamiński, t. 2 (Warszawa: Instytut 


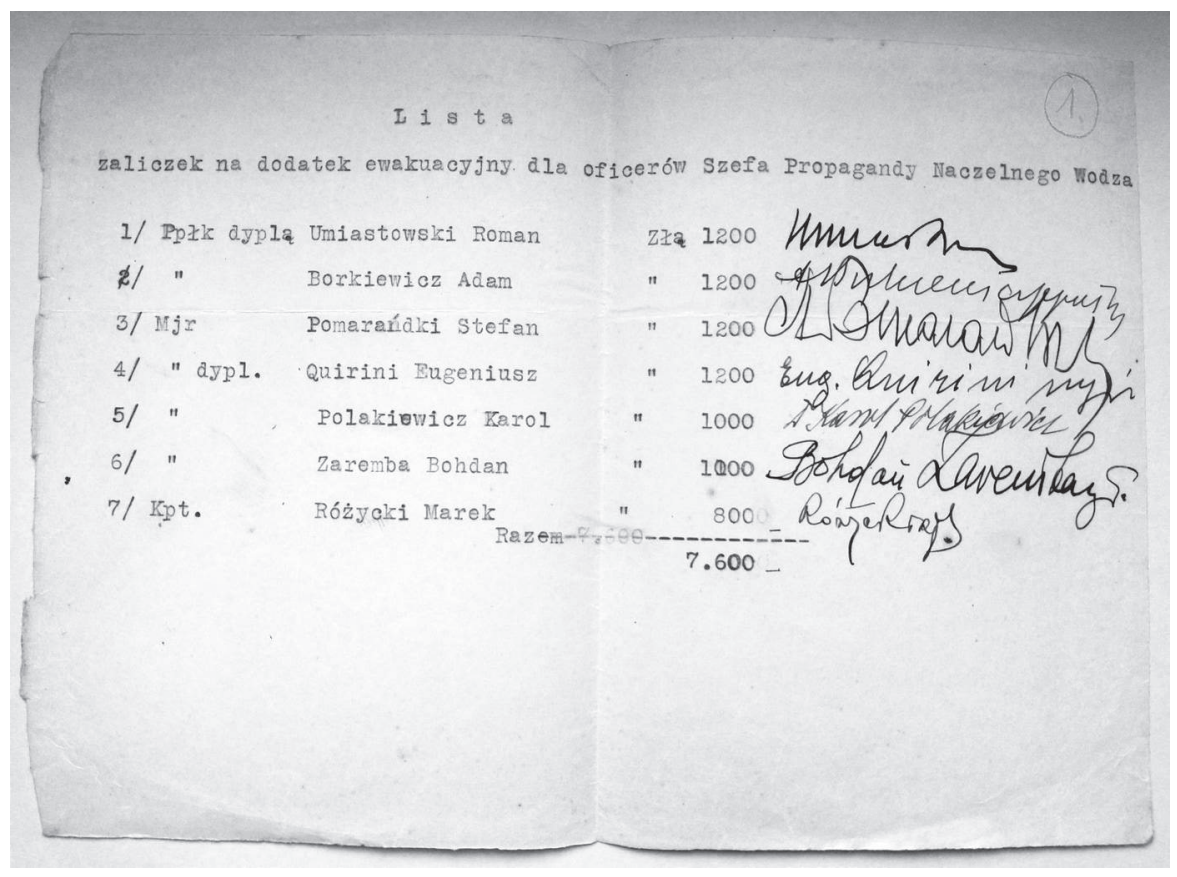

Lista zaliczek na dodatek ewakuacyjny oficerów BP NW.

Źródło: Archiwum Prywatne Rodziny Quirini

1940 r. sformowano na terenie Francji: Samodzielną Brygadę Strzelców Podhalańskich (dowódca płk/gen. bryg. Zygmunt Szyszko-Bohusz); 1 Dywizję Grenadierów (dowódca płk dypl./gen. bryg. Bronisław Duch); 2 Dywizję Strzelców Pieszych (dowódca gen. bryg. Bronisław Prugar-Ketling); 4 Dywizję Piechoty (dowódca gen. bryg. Rudolf Dreszer); 10 Brygadę Kawalerii Pancernej (dowódca gen. bryg. Stanisław Maczek) oraz zaczęto formować 3 Dywizję Piechoty (dowódca płk dypl. Tadeusz Zieleniewski). ${ }^{22}$

Sytuacja organizowanych na terenie Francji polskich oddziałów wojskowych liczących około 84 tys. żołnierzy stała się niezwykle trudna po kapitulacji Francji 17 czerwca oraz podpisaniu 22 czerwca niemiecko-francuskiego układu o zawieszeniu broni. ${ }^{23} \mathrm{~W}$ związku z tym polscy żołnierze

Pamięci Narodowej, 2009), 13; Olgierd Terlecki, Generat Sikorski, t. 1 (Kraków: Wyd. Literackie, 1981), 157, 164, 210.

22 Biegański, Wojsko, 185-215; Bielak, „Ewakuacja,” 14; Smoliński, Ewakuacja Wojska Polskiego do Wielkiej Brytanii w czerwcu 1940 (Warszawa: Egros, 1996), 9-11.

23 Smoliński, Ewakuacja, 5; Biegański, Finał dziwnej wojny. Studium o kampanii francuskiej 1940 (Warszawa: Wyd. Ministerstwa Obrony Narodowej, 1970), 335-339; Janusz Zuziak, „Wysiłek mobilizacyjno-organizacyjny Polskich Sił Zbrojnych na Zachodzie w drugiej wojnie światowej," Piotrkowskie Zeszyty Historyczne 5, (2003): 240; Terlecki, Generał, 1:267-268. 
znajdujący się na terenie Francji, nie chcąc złożyć broni lub dostać się do niemieckiej niewoli, na podstawie rozkazu premiera i zwierzchnika PSZ gen. Sikorskiego z 19 czerwca mieli kierować się do zachodnich jej portów. ${ }^{24}$ Równocześnie premier spotkał się $\mathrm{w}$ Bordeaux $\mathrm{z}$ nowym premierem francuskim marsz. Philippem Petainem, którego poinformował, że bez względu na decyzje rządu francuskiego rząd polski oraz polska armia nie złożą broni i będą kontynuować walkę wspólnie z Wielką Brytanią. ${ }^{25}$ Pomimo nieprzyjaznej postawy Francuzów i odmowy udzielenia jakiejkolwiek pomocy w okresie pomiędzy 19 a 25 czerwca z terenów francuskich wyjechało około $40 \%$ żołnierzy polskich przebywających we Francji. ${ }^{26}$ Aby umożliwić ich ewakuację do Wielkiej Brytanii, Sikorski już 19 czerwca podjął rozmowy z premierem Winstonem Churchillem, uzyskując zapewnienie rządu angielskiego o kontynuowaniu wspólnej walki z najeźdźcą niemieckim. ${ }^{27}$ Równocześnie zdecydowano o wysłaniu polskich („Batory” i „Sobieski”) i angielskich statków do portów francuskich w celu ewakuacji polskich żołnierzy ${ }^{28} 22$ czerwca 1940 r. delegacja francuska podpisała zawieszenie broni z Niemcami, nie troszcząc się o los pozostałych na terenie Francji bez żadnych środków do życia wiernych polskich sojuszników. ${ }^{29}$

Zamieszczone poniżej wspomnienie ppłk. dypl. Eugeniusza Quiriniego to przygotowany do druku w latach sześćdziesiątych XX w. artykuł, który nigdy nie był publikowany. 1 grudnia $1970 \mathrm{r}$. nie został przyjęty do druku w tygodniku „Za i Przeciw” przez redaktora Władysława Minkiewicza (odpowiedź Warszawa: z L. dz. 499/70). Tekst miał formę maszynopisu i znajduje się w Archiwum Prywatnym Rodziny Quirini. Poprawiono w nim ortografię i interpunkcję w koniecznym z punktu widzenia dzisiejszego czytelnika zakresie. Wszelkie dopiski w nawiasach kwadratowych pochodzą od wydawcy.

24 Smoliński, „Wysiłek wojenny Polskich Sił Zbrojnych na Zachodzie (1939-1945)," Niepodległość i Pamięć 26, nr 4 (2019): 98; Smoliński, „Koncepcje formowania i użycia Wojska Polskiego we Francji (wrzesień 1939-czerwiec 1940)," Niepodległość i Pamięć 24, nr 2 (2017): 167-169; Smoliński, Ewakuacja, 19, 24.

25 Smoliński, Ewakuacja, 32-33; Biegański, Finał, 335-339; Zuziak, „Wysiłek mobilizacyjno-organizacyjny," 240.

26 Biegański, Polskie Siły Zbrojne na Zachodzie 1939-1945 (Warszawa: Krajowa Agencja Wydawnicza, 1990), 11.

27 Terlecki, Generał, 1:281-283.

28 Smoliński, Ewakuacja, 22; Smoliński, „Działalność naczelnych władz wojskowych podczas ewakuacji wojska polskiego do Wielkiej Brytanii w czerwcu 1940 r.," Niepodległość i Pamięć 6, nr 2 (1999): 222-228; Armia polska i życie społeczne Polaków we Francji. Wrzesień 1939-czerwec 1940, wybór i oprac. Marian Drozdowski i Smoliński (Warszawa: Typografika, 2001), 143; Terlecki, Generał, 1:286.

29 Terlecki, Generat, 1:289. 


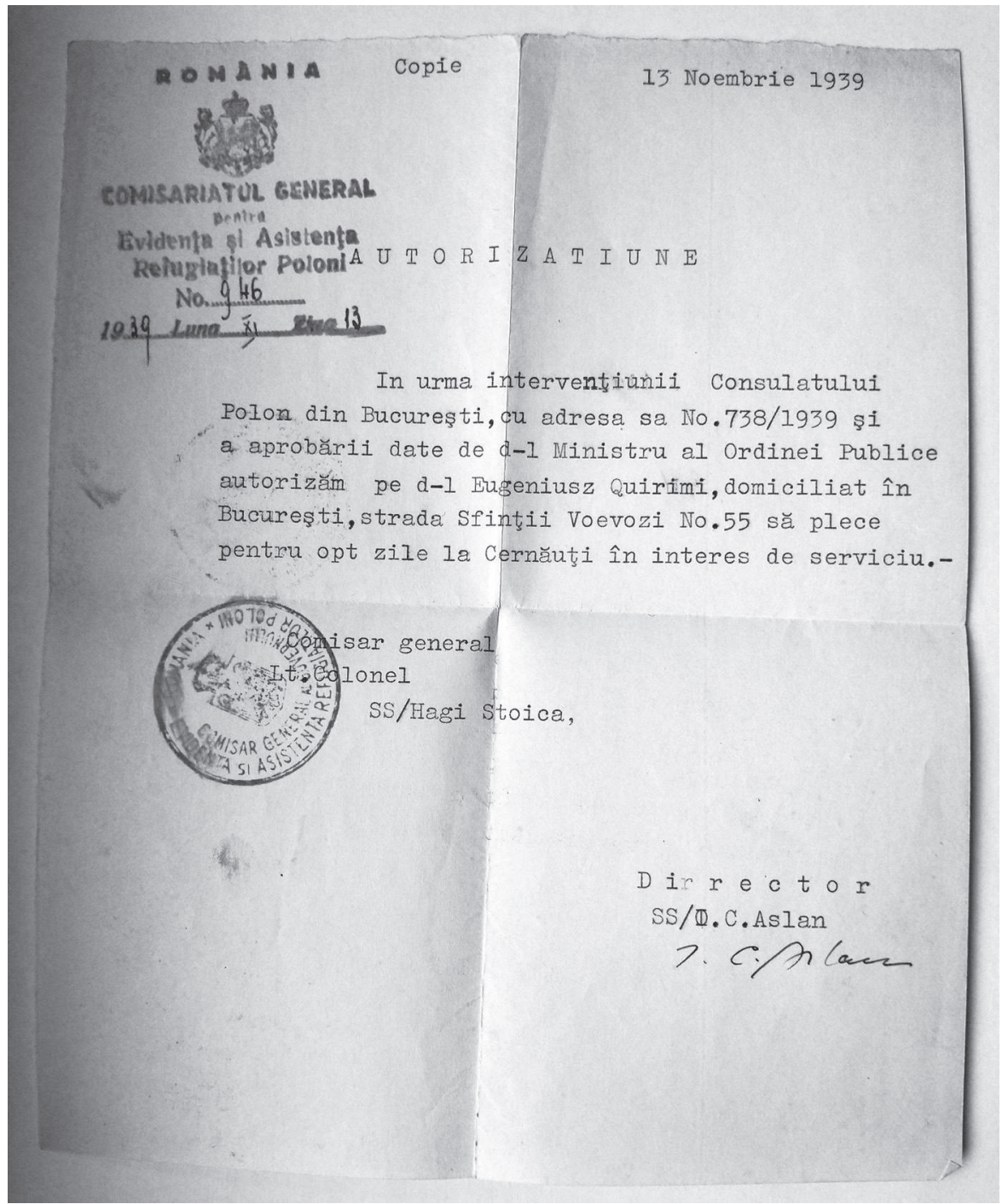

Upoważnienie do wyjazdu do Bukaresztu z 13 listopada 1939 r. Źródło: Archiwum Prywatne Rodziny Quirini

Gdy przybyliśmy do Francji pod sam koniec 1939 r., zastaliśmy tu nastrój ponury, a przede wszystkim kontynuacji wojny niechętny. Część mieszkańców Paryża nadal się bawiła, bagatelizując nadchodzące niebezpieczeństwo, także rygory wojenne dotyczące m.in. zaciemniania okien były słabo przestrzegane. Opinia publiczna głosiła, że wojna jest wynikiem złej polityki Polski, a głośnym echem odbiły się wśród Polaków napływających 
z okupowanego kraju treści artykułu polityka, posła i publicysty Marcelego Déat'a pt. Nous ne voulons pas mourir pour Dantzig30 opublikowanego w czasopiśmie L'Oeuvre jeszcze 4 maja 1939 r. Odzwierciedlał on najlepiej nastroje szerokich rzesz Francuzów, dla których konflikt Polski z Niemcami był wynikiem nierozważnej polityki jej ówczesnych władz. Tocząca się wojna Francji z Niemcami była niepopularna i należało ją, drôle de guerre!, tą dziwną, śmieszną wojnę jak najprędzej zakończyć. Gdzieniegdzie dochodziło nawet do scysji i gorących dyskusji na ten temat pomiędzy Francuzami a Polakami. Żołnierz francuski raczej nie miał awersji do Polaków, ale nie chciał się bić. To nie byli ci bohaterscy poilu ${ }^{31} \mathrm{z}$ I wojny światowej oraz sojusznicy w walkach z bolszewikami z 1920 r.! Defetyzm panował ogólnie, dyscyplina $\mathrm{w}$ wojsku francuskim nie była nadzwyczajna i do tego nieprzestrzegana.

Wkrótce zresztą zostałem przeniesiony z Paryża do Stacji Zbornej Oficerów w obozie Camp de Carpiagne, położonym na południe od Marsylii. Obóz znajdował się niedaleko miasteczka Cassis, leżącego tuż nad Morzem Śródziemnym, gdzie korzystając z pięknej pogody, można było zażywać przyjemnej kąpieli. Stacja Zborna miała za zadanie przyjmowanie oficerów przybywających z różnych stron, bądź drogą morską do Marsylii, bądź koleją z Jugosławii, Węgier, Rumunii, a nawet z Grecji. Przeważnie byli to uczestnicy kampanii wrześniowej, ale także odważni ochotnicy z kraju, którym udało się przedostać przez liczne kordony graniczne. Zgłaszający się żołnierze $\mathrm{z}$ zasady nie posiadali żadnych dokumentów osobistych, co $\mathrm{w}$ tych warunkach było zrozumiałe, ale co ogromnie utrudniało ich weryfikację. Większość stanowili oczywiście oficerowie rezerwy, a więc sprawdzanie stopni i ich przydatności bojowej nie było łatwe, zwłaszcza u osób pochodzących z Kresów. Praca kulturalno-oświatowa oprócz przygotowania programów i ich wdrażania w życie wymagała zachowania dużej ostrożności. Trzeba było bowiem bardzo uważać, aby nie dopuścić do przenikania elementów szpiegowskich. Ponieważ przydzielona mi grupa oficerów piechoty była najliczniejsza, przeto miałem sporo pracy. Stacja prowadziła działalność wychowawczą oraz oświatową. Ministerstwo Spraw Wojskowych na uchodźstwie utworzyło Wydział Propagandy i Oświaty, który podlegał bezpośrednio pierwszemu wiceministrowi. Wydział składał się z dwóch referatów - propagandy, którym kierował major Edward Ligocki, natomiast referat oświaty przydzielono mnie.

\footnotetext{
30 Franc. „My nie chcemy umierać za Gdańsk”.

31 Określenie żołnierzy francuskich z czasów I wojny światowej. Pochodzi od słowa poil włos. Można je tłumaczyć jako „owłosiony” lub „włochaty”, a brało się z owłosienia twarzy, jakie nosili francuscy piechurzy.
} 


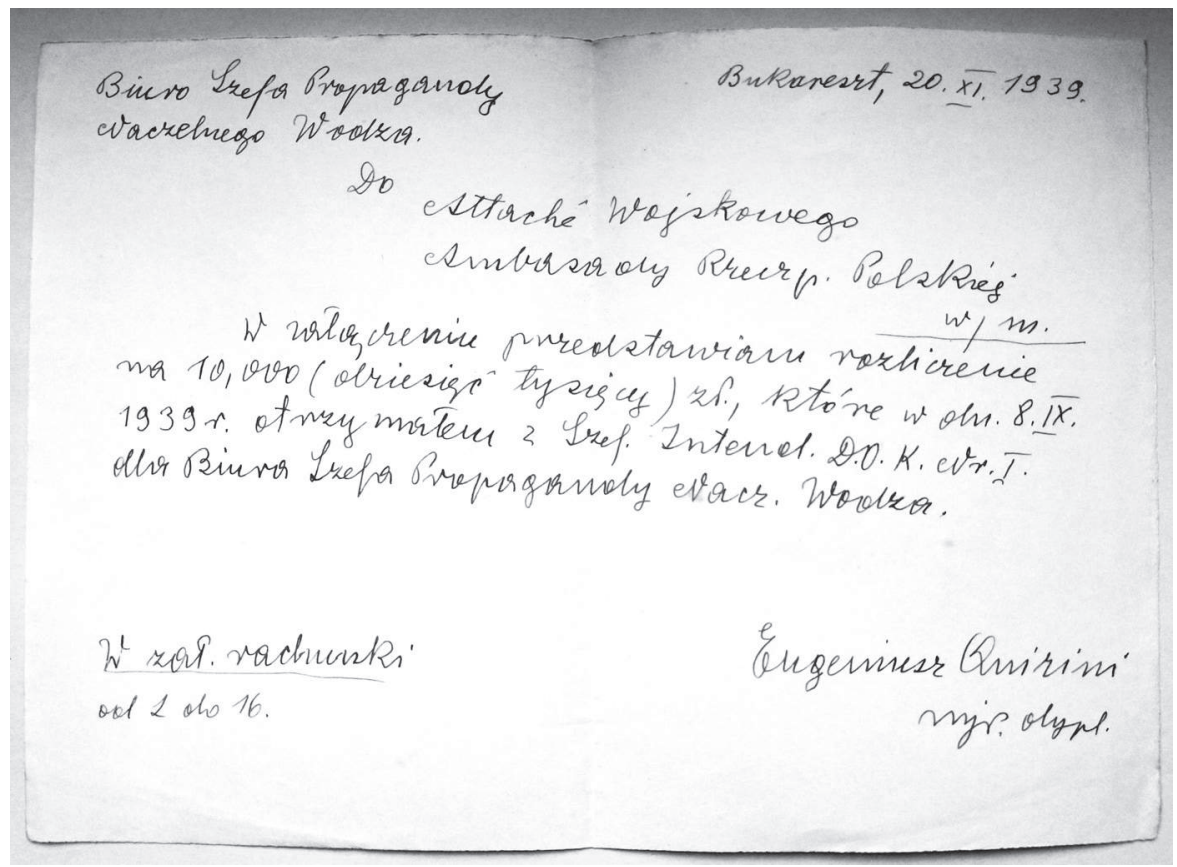

Rozliczenie środków otrzymanych dla Szefa BP NW 8 IX 1939 r., Bukareszt, 20 XI 1939 r. Źródło: Archiwum Prywatne Rodziny Quirini

Polskim komendantem do spraw wojskowych obozu w Camp de Carpiagne był pułkownik Sz. ${ }^{32}$, a jego zastępcą podpułkownik $\mathrm{Cz}^{33}$, obaj powołani ze stanu spoczynku do służby czynnej i obaj pochodzący z byłej armii carskiej. Podpułkownik Cz. chlubił się nawet noszoną na lewej ręce złotą bransoletką z odznaką pułku gwardii carskiej, w którym niegdyś służył. Komendantem francuskim był pułkownik Petit ${ }^{34} \mathrm{z}$ wojsk kolonialnych,

32 Autor zapisał nazwisko Szuszkiewicz w swoim kalendarzyku pod datą 18 VI 1940 r., zob. Archiwum Prywatne Rodziny Quirini, Kalendarzyk Agenda na rok 1940 Eugeniusza Quirini, b.m., 18 VI 1940 r., b.p. Prawdopodobnie oficerem tym był Antoni Szuszkiewicz (ur. 9 XII 1886 - zm. 28 III 1979) - płk, kawalerzysta, uczestnik wojny polsko-bolszewickiej, dowódca m.in. 14 Pułku Ułanów Jazłowieckich, zob. Daniel Koreś, „Antoni Szuszkiewicz (1886-1979)," PSB 49, z. 3 (2014): 407.

33 Autor zapisał nazwisko Czerwiński w swoim kalendarzyku pod datą 18 VI 1940 r., zob. ibid. Prawdopodobnie chodziło o Stanisława Czerwińskiego (ur. 1 XI 1896 r. - zm. ?) - mjr. piech. W kampanii polskiej 1939 r. kwatermistrz 54 Pułku Piechoty.

34 Ernest Petit (ur. 1886 - zm. 20 V 1971 w Saint Maur des Fosses) - w randze kpt. brał udział w I wojnie światowej, podczas której został wzięty w 1916 r. do niewoli niemieckiej i przetrzymywany w Forcie Ingolstadt wraz z Charlesem de Gaullem. Po ucieczce powrócił na front. Po zakończeniu wojny został oddelegowany jako dowódca do Maroka (19181920), następnie odkomenderowany do Niemiec, gdzie służył od 1920 do 1924 r. W latach 


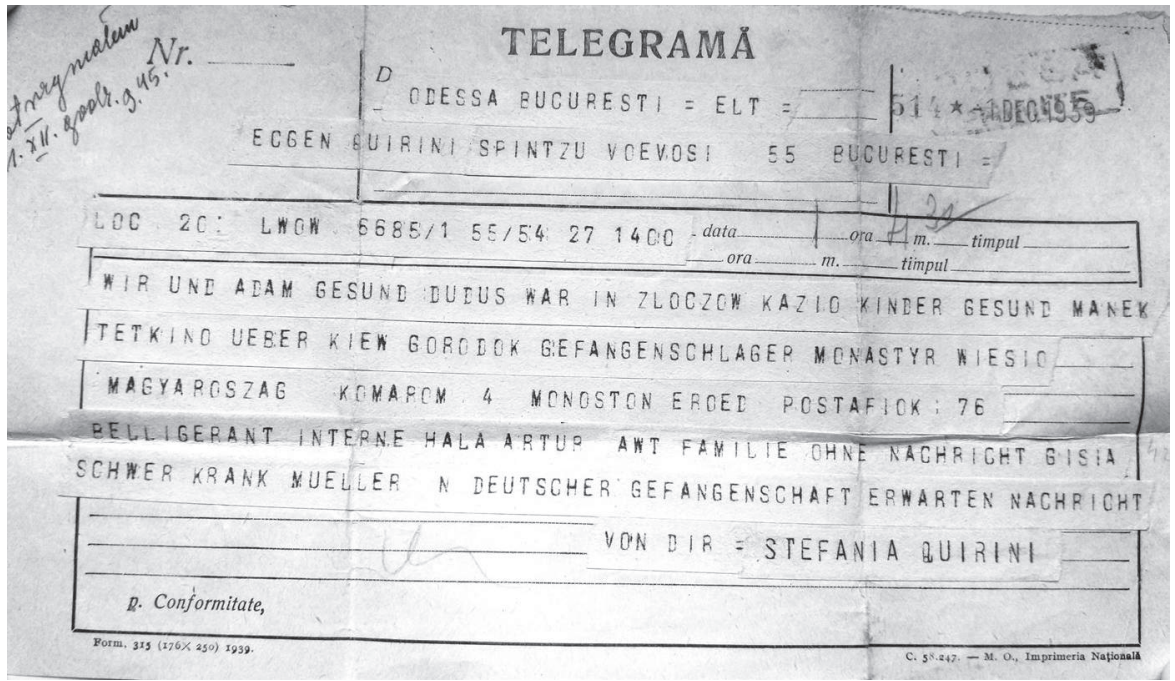

Telegram od Stefanii Quirini wysłany do Eugeniusza Quiriniego do Bukaresztu. Źródło: Archiwum Prywatne Rodziny Quirini

niski, krępy, bardzo ruchliwy i energiczny. Odnosił się do nas życzliwie, ale ostro. Po obiedzie palił cygara, które [sic!] jednakże często zapominał, tak że ja zawsze miałem je w pogotowiu. Nabrał do mnie respektu nie tylko z powodu znajomości języka francuskiego, ale ze względu na rygorystyczne przestrzeganie regulaminu wojskowego. Jednym $\mathrm{z}$ tego dowodów był fakt, że w czasie niespodziewanego alarmu nocnego zjawiłem się jako pierwszy na placu zbiórki z całym plutonem służbowym. Był to alarm spowodowany nalotem samolotów włoskich, wkrótce po wypowiedzeniu Francji wojny przez Włochy.

1924-1926 był stażystą w École Supérieure de Guerre, następnie został przydzielony do sztabu Lewantu, gdzie służył do 1934 r. W latach 1934-1936 był wykładowcą taktyki w Laison School, a następnie mianowany szefem francuskiej misji wojskowej w Paragwaju. Po upadku Francji przebywał w Wielkiej Brytanii, w 1941 r. został szefem sztabu generała de Gaulle’a w Londynie oraz w listopadzie tego roku awansował na gen. bryg. Był członkiem Francuskiego Komitetu Wyzwolenia Narodowego i jako jego szef odbył misję wojskową w Moskwie i w Kujbyszewie (lipiec 1943 r.). Sympatyzował z komunistami, był obecny przy formowaniu 1 Dywizji Piechoty im. Tadeusza Kościuszki przez Zygmunta Berlinga. Po wyzwoleniu w 1945 r. mianowany gen. dyw., nast. gen. korpusu. W 1947 r. stanął na czele gabinetu wojskowego ministra obrony narodowej François Billoux, został wybrany senatorem. Uczestniczył aktywnie w życiu politycznym Francji. Zasiadał w Radzie Republiki, w Komisji obrony narodowej ds. cudzoziemców, dokonywał interwencji w sprawie wojny algierskiej. Przywiązany do koncepcji przyjaźni między narodami, popierał stowarzyszenia ZSRR-Węgry, Francja-Wietnam oraz Francja-Chiny, był członkiem Narodowej Rady Ruchu Pokojowego. Odwiedzał liczne kraje, m.in. Polskę w 1957 r., był też wówczas w Krynicy Zdroju. 


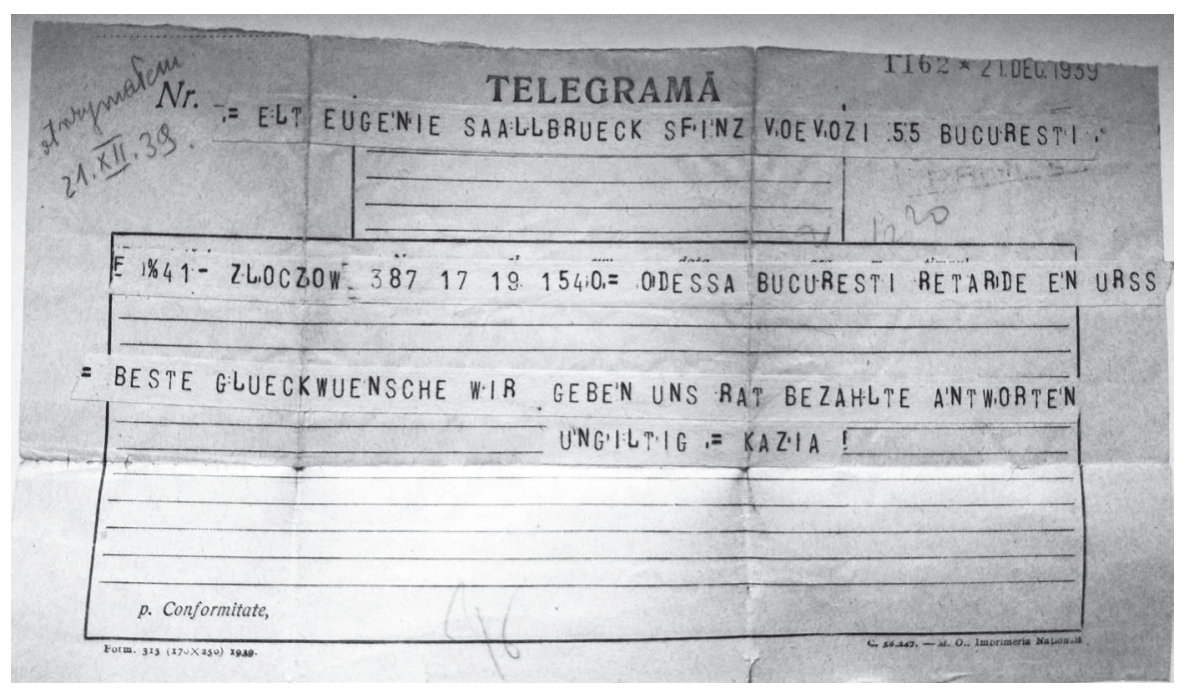

Telegram od „Kazi” do Eugeniusza Quiriniego w Bukareszcie.

Źródło: Archiwum Prywatne Rodziny Quirini

W obozie działała bardzo sprawnie polska YMCA (Young Men's Christian Assotiat [sic!]). ${ }^{35}$ Większość jej pracowników stanowili dawni działacze z Polski, którzy pracowali z całym zapałem, prowadząc świetlicę i różne zajęcia dla żołnierzy, wspomagając znacznie nasze działania. Jej amerykańscy opiekunowie dostarczali im cały sprzęt oraz żywność, a z posiłków przez nich przygotowywanych korzystała znaczna część stacjonujących żołnierzy w obozie. Poza tym w świetlicy odbywały się odczyty m.in. na aktualne tematy dotyczące bieżącej sytuacji politycznej, lekcje historii, geografii oraz języka polskiego i francuskiego, które to zajęcia wywierały dobroczynny wpływ na skołatanych polskich rozbitkach.

W sobotę 15 czerwca $1940 \mathrm{r}$. jeden z naszych oficerów przybył do kasyna bardzo podniecony, mówiąc, że podoficerowie francuscy poprosili go po drodze, aby wysłuchał najnowszej audycji radiowej, w której była mowa o armistice - czyli zawieszeniu broni. Na to pułkownik Petit $\mathrm{z}$ wielką irytacją zawołał, że za szerzenie niepokojących informacji grozi sąd polowy. $\mathrm{W}$ niedzielę $\mathrm{w}$ miasteczku wiadomość ta była już ogólnie kolportowana, a w poniedziałek 17 czerwca wszystkie gazety ogłosiły na pierwszych stronach wiadomość, że marszałek Philippe Petain podpisał zawieszenie broni. Wiadomość ta była dla nas jakby niespodziewanym piorunem $\mathrm{z}$ nieba!

35 Właśc. Young Men’s Christian Association - Związek Chrześcijańskiej Młodzieży Męskiej, organizacja założona w 1844 r. w Londynie, działająca do dziś. W Polsce od 1919 r. Program tej międzynarodowej organizacji ekumenicznej oparty jest na wartościach chrześcijańskich. 
Wszyscy byliśmy przygotowani na długą wojnę obronną we Francji. Wojsko Polskie wystawiło już dwie dywizje piechoty i brygadę pancerną, które wraz z lotnictwem polskim biły się już na wschodnim i północno-wschodnim froncie francuskim, a w toku organizacji były następne dwie dywizje. Olbrzymi potencjał wojenny Francji i linia Maginota - wszystko zawiodło i Francja padła nieoczekiwanie szybko, prawie (niemal) bez obrony!

Po nadejściu wiadomości o kapitulacji oficerowie francuscy zebrani razem z nami w kasynie przeszli do sąsiedniego pokoju, kiedy wrócili, wielu z nich miało oczy zaczerwienione, widać było, że płakali. Pułkownik Petit zarządził pożegnalną kolację dla polskich oficerów, z tym że szampan miał być otwierany w ukryciu. Gdy wyszliśmy załamani, nie dowierzając usłyszanym wiadomościom na ulice miasteczka, spotkaliśmy gromady idących razem żołnierzy, marynarzy i robotników w dobrych humorach, cieszących się i wznoszących okrzyki Vive la France, Vive l'armistice, Vive Maréchal Pétain! Jak zobaczyli nas, rozległy się okrzyki Vive la Pologne! Jeden z robotników zapytany przeze mnie, dlaczego tak się cieszą, odpowiedział: że dobrze, że to się skończyło, bo jak Niemcy przyjdą, to i tak muszą im płacić, jak będą pracować. $\mathrm{W}$ ich więc położeniu zasadniczo nic się nie zmieni. $\mathrm{Z}$ tej argumentacji widać było całkowitą obojętność co do losów ich ojczyzny i zupełny brak patriotyzmu.

Po południu 17 czerwca 1940 r. pułkownik Sz[uszkiewicz] zarządził zbiórkę całej Stacji Zbornej (samych oficerów było 371), na której ogłosił po krótkim przemówieniu swoją decyzję stojącym w szeregach kompaniom oficerskim. Stacja Zborna zostaje rozwiązana, wszyscy dostaną rozkazy wyjazdu, pieniądze na drogę i mogą jechać, gdzie chcą. Skądinąd doszły do nas informacje, że rząd francuski pragnie zatrzymać Wojsko Polskie i nie dopuścić do jego wyjazdu z Francji. W tej sytuacji wszyscy dostalibyśmy się do niewoli niemieckiej!

Można sobie wyobrazić, jakie wrażenie wywarły z jednej strony informacje władz francuskich, a $\mathrm{z}$ drugiej zarządzenie komendanta obozu na zgromadzonych żołnierzach, którzy niejednokrotnie po ciężkich przejściach dotarli do Francji. Jak można tych ludzi bez dokumentów i bez pieniędzy, w większości nieznających języka francuskiego, puszczać na pastwę nadchodzących Niemców? A przecież z rozkazu Naczelnego Wodza Polskich Sił Zbrojnych Władysława Sikorskiego wyraźnie wynikało, że wszyscy wojskowi Polacy mają się starać za wszelką cenę przedostać do zachodnich portów francuskich i wyjechać do Anglii. Naszym więc obowiązkiem jest pomóc im w tej ciężkiej sytuacji!

Gdy na zbiórce 17 czerwca zebrali się oficerowie naszej kadry, zacząłem przemawiać $\mathrm{w}$ tym duchu, toteż wkrótce inni oficerowie $\mathrm{z}$ komendy obozowej mnie poparli. Stanęło na tym, że musimy postarać się wszystkich żołnierzy ewakuować. Niestety szybko się okazało, że wykonanie tego 


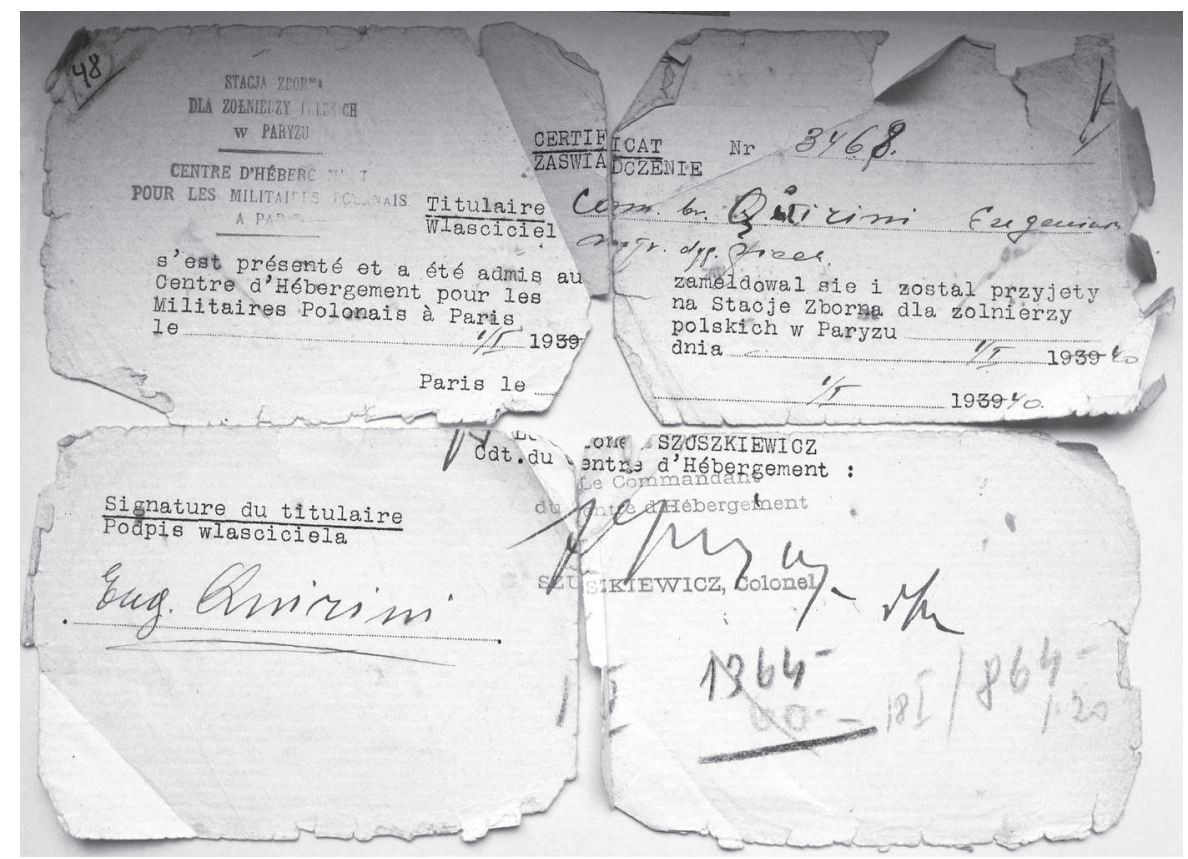

Zaświadczenie ze Stacji Zbornej dla Oficerów.

Źródło: Archiwum Prywatne Rodziny Quirini

zadania napotkało na poważne trudności. Mieliśmy tylko dwa samochody ciężarowe, a więc trzeba było wziąć pod uwagę skorzystanie z kolei. Zdawaliśmy sobie sprawę, że nie będzie możliwe, aby władze francuskie mogły nam w obliczu niemieckiego natarcia zapewnić transport kolejowy. A jednak udało się i przy pomocy naszych Francuzów obozowych dostaliśmy specjalny pociąg nazajutrz tj. 18 czerwca popołudniu. ${ }^{36}$ Ponieważ ja tak mocno agitowałem za ewakuacją naszych żołnierzy, powierzono mi funkcję oficera załadowczego. Komendantem transportu został pułkownik Lichtarowicz $^{37}$. Pułkownicy Sz[uszkiewicz] i Cz[erwiński] mieli już przygotowane swoje prywatne samochody solidnie wyładowane $\mathrm{z}$ przyczepami oraz

36 Archiwum Prywatne Rodziny Quirini, Kalendarzyk Agenda na rok 1940 Eugeniusza Quiriniego, [Carpiagne], 18 VI 1940 r., b.p.; Kalendarzyk Adrien na rok 1940 r. Eugeniusza Quiriniego, [Carpiagne], 18 VI 1940 r., b.p. 18 czerwca miał miejsce wyjazd ze Stacji Zbornej Carpiagne. 37 Ludwik Lichtarowicz (ur. 1890 w Bobrujsku - zm. 1965 w Londynie) - ukończył prawo w Petersburgu, służbę rozpoczął w armii Imperium Rosyjskiego, absolwent Mikołajewskiej Akademii Sztabu Generalnego. W 1919 r. przedostał się do Polski i wziął udział w wojnie polsko-bolszewickiej 1920 r. Następnie w Polsce ukończył I Kurs Doszkolenia w WSWoj. W 1926 r. opowiedział się po stronie legalnych władz, a po przegranej kampanii polskiej 1939 r. przedostał się do Francji, następnie w czerwcu 1940 r. do Wielkiej Brytanii. Tu otrzymał przydział do 7 Brygady Kadrowej Strzelców. Po II wojnie światowej pozostał na emigracji. 
paszporty z wizami. Tegoż dnia popołudniu wraz z żonami i adiutantem wyjechali w kierunku hiszpańskiej granicy. ${ }^{38}$

Cały transport z Carpiagne obejmował 513 ludzi, udało mi się go sprawnie załadować. Oczywiście w Marsylii dołączył do nas personel polskiego szpitala wojskowego, komendy placu, konsulatu polskiego itd., ale w każdym wagonie miałem pozostawione wolne miejsca. Żołnierzy pochodzących z polskiej emigracji we Francji, którzy chcieli pozostać i wrócić do swoich domów, zwolniłem na podstawie rozkazu generała Władysława Sikorskiego za odpowiednim zaświadczeniem, część spośród nich odjechała z nami.

Początkowo transport nasz skierowany został na Bordeaux. Ale teraz zaczęły się trudności z przepychaniem pociągu przez stację zawaloną różnego rodzaju transportami ewakuacyjnymi, a to wojska, artylerii z linii Maginota oraz ludności cywilnej itd. Gdy przybyliśmy 19 czerwca w nocy na stację Nimes (o ile sobie dobrze przypominam), oświadczono nam, że transport nasz dalej nie pojedzie. Posłałem porucznika i chorążego (obaj byli z Francji), wręczając im 500 franków i butelkę wina do rozdzielni nastawniczej i około 2 w nocy pociąg ruszył. Po drodze dostawaliśmy na stacjach prowiant, a nawet i wina. Drugi gorszy korek miał miejsce następnej nocy na jakiejś stacji pod Tuluzą, której nazwy nie pamiętam (może Sete?). ${ }^{39}$ Tu odczepiono lokomotywę, która odjechała, zostawiając nasz pociąg na zatłoczonej stacji. Ponieważ długie pertraktacje moich wysłanników nie dały rezultatu, wobec tego wziąłem porucznika, chorążego z dziesięcioma uzbrojonymi żołnierzami i udałem się do francuskiego kapitana, komendanta dworca. Oświadczyłem mu, że o ile zaraz nie da nam parowozu, to weźmiemy go sobie sami siłą. Z początku się stawiał, ale po kilku telefonach powiedział mi, że lokomotywa będzie. Dla pewności posłałem porucznika z kilkoma żołnierzami do parowozowni i za kwadrans pociąg ruszył ku naszemu zadowoleniu.

Przybywszy 20 czerwca około godziny 8:30 do Tuluzy, dowiedzieliśmy się, że Bordeaux jest już bombardowane przez lotnictwo niemieckie, a nasz transport zostanie skierowany do Bayonne. Do tej stacji przybyliśmy (mijając około godziny 13:15 miasto Tarbes, a następnie Lourdes) w nocy 20 czerwca wśród ulewnego deszczu. ${ }^{40} \mathrm{~W}$ pociągu spędziliśmy całą noc. Rano dowiedzieliśmy się, że mamy się dostać do małego portu rybackiego Saint Jean de Luz (położonego około 20 kilometrów stąd), blisko granicy hiszpańskiej. 21 czerwca około godziny 10 rozpoczęliśmy wyładowywanie bagaży, różnych pakunków, worków i waliz. Okazało się bowiem, że z tą

\footnotetext{
38 Archiwum Prywatne Rodziny Quirini, Kalendarzyk Agenda na rok 1940 r. Eugeniusza Quiriniego, [Carpiagne], 18 VI 1940 r., b.p.

39 W kalendarzyku Adrien została zanotowana miejscowość Sete.

40 Dokładne informacje dotyczące trasy zostały zapisane w obu kalendarzykach pod datą 20 VI 1940 r.
} 


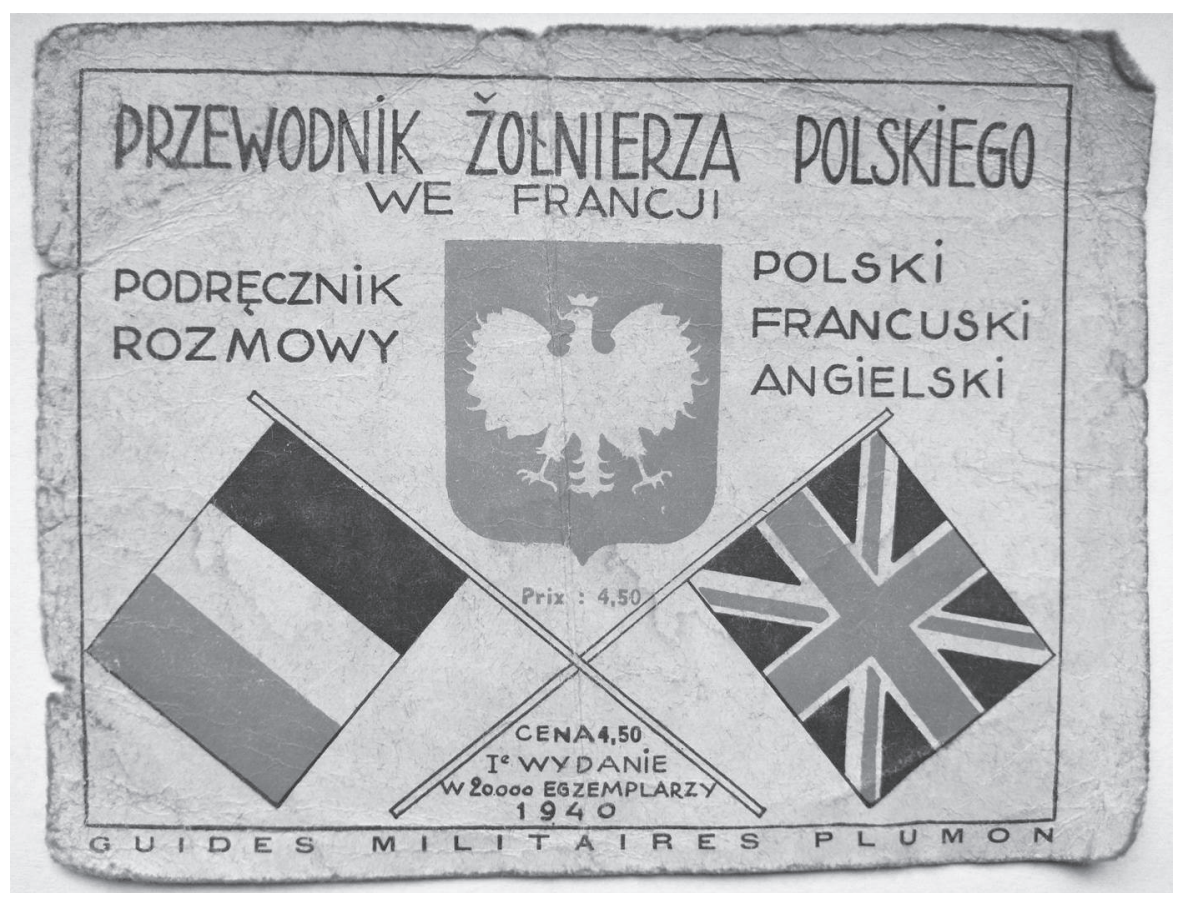

Przewodnik Żołnierza Polskiego we Francji z 1940 r.

Źródło: Archiwum Prywatne Rodziny Quirini

osadą nie ma niestety połączenia kolejowego, więc musielibyśmy iść pieszo. Pułkownik Lichtarowicz załadował na jedną ciężarówkę oficerów kadry, a na drugą ich bagaże i wezwał mnie, abym jechał z nimi, a pozostali oficerowie i żołnierze mieli maszerować. Gdy ja odmówiłem, pułkownik machnął ręką i odjechał. Ponieważ wszędzie po drodze stały francuskie ciężarówki przeważnie opuszczone przez kierowców, więc postanowiłem je wykorzystać. Wybrałem kilku oficerów umiejących prowadzić samochód i wysłałem ich na poszukiwania. Za chwilę ciężarówki zaczęły przyjeżdżać jedna za drugą, a maszerujące dotąd kompanie zaczęły odjeżdżać. Ja wsiadłem razem z ostatnią czwartą kompanią i w ten sposób dojechaliśmy 21 czerwca około godziny 16 do Saint Jean de Luz. Myślałem, że czeka nas długa i niebezpieczna podróż barkami rybackimi do Anglii, tymczasem ledwie wysiadłem z wozu, już usłyszałem głosy, że „Batory" ${ }^{41}$ i „,Sobieski”" ${ }^{22}$ są

${ }^{41}$ MS „Batory” - polski statek pasażerski, transatlantyk, zbudowany we włoskiej stoczni w Monfalcone. Uroczyste jego wodowanie nastąpiło 3 VII 1935 r. W grudniu 1939 r. przyjęła go brytyjska admiralicja, przebudowany i uzbrojony rozpoczął służbę wojenną pod polską banderą. 42 Transatlantyk „Sobieski” został zaprojektowany jako statek transportowo-pasażerski, zwodowany w angielskiej stoczni Swan Hunter and Wigham Richard w 1937 r. Podniesienie 
w porcie i ku memu zdumieniu ujrzałem oba nasze transatlantyki kołyszące się majestatycznie na redzie.

Na molo stały masy skrzyń wojskowych, moc eleganckich waliz i kufrów, motocykle, samochody itd. Wraz z żołnierzami pomagałem jeszcze w przenoszeniu bagaży na statek, ale na wezwanie kapitana Borkowskiego $^{43} \mathrm{z}$ Batorego rzuciliśmy wszystko i podjechaliśmy na statek. Dostałem wygodną kajutę razem z podpułkownikiem Wincentym Kurkiem ${ }^{44}$, który zginął potem pod Monte Cassino. 22 czerwca 1940 r. załadowanie przeszło 3 tys. osób (w tym kompletnego batalionu saperów i 300-400 osób cywilnych), trwało do godziny 18 , po czym Batory ruszył. ${ }^{45}$ Poszedł zygzakami na zachód z dala od brzegów, oczywiście bez żadnej eskorty. Sobieski wypłynął przed nami. Obok innych oficerów zostałem przydzielony do służby inspekcyjnej na statku od godziny 12 do 6 rano. Równocześnie 23 czerwca wyznaczono mnie do komisji przeprowadzającej ewidencję osób cywilnych (Francuzów, Hiszpanów[,] Niemców - przeciwników Hitlera, a także Żydów), uciekających przed hitlerowcami. ${ }^{46}$

Po południu ogłoszono na statku alarm ćwiczebny. Wszyscy zebrali się na wyznaczonych miejscach, kobiety z dziećmi przy łodziach, oficerowie przy tratwach, żołnierze przy pasach ratunkowych. W każdej grupie

polskiej bandery z powodu opóźnienia dostaw materiałowych miało miejsce dopiero w 1939 r. Po wybuchu II wojny światowej i przystosowaniu go do pełnienia funkcji transportowca wojskowego uczestniczył w operacjach wojennych.

43 Kapitan Eustachy Borkowski (ur. 1887 - zm. 1968) - ukończył Szkołę Morską w Rydze, pływał początkowo na statkach floty rosyjskiej, przez 10 kolejnych lat przebywał we Francji. Do kraju powrócił w 1929 r., uzyskując kwalifikacje kapitańskie. W 1931 r. został kapitanem transatlantyku MS „Kościuszko”, dzięki niewątpliwym zdolnościom oraz talentowi oratorskiemu zdobył popularność wśród pasażerów, uzyskując tytuł Szamana Morskiego. Kolejno dowodził „Pułaskim”, a od 1936 r. „Batorym”. Wedle znawców tematu został odwołany z zajmowanego stanowiska i 22 IX 1939 r. opuścił pokład „Batorego”. Od 1940 r. (po stracie „Chrobrego”) „Batorym” dowodził kapitan żeglugi wielkiej Zygmunt Deyczakowski (ur. 1905 - zm. 1979). On to więc uczestniczył w ewakuacji polskich i zagranicznych żołnierzy z Francji do Wielkiej Brytanii.

44 Wincenty Kurek (ur. 1895 - zm. 17 V 1944) - płk piechoty WP. Podczas I wojny światowej dostał się do niewoli rosyjskiej, w 1920 r. mianowany por., w 1930 r. mjr., a w 1934 r. ppłk., następnie oddelegowany został do 28 Pułku Strzelców Kaniowskich w Łodzi. Od czerwca 1939 r. pełnił funkcję komendanta Centrum Wyszkolenia Piechoty. Po upadku Polski dostał się przez Rumunię do Francji, a następnie do Wielkiej Brytanii. W 1942 r. mianowany pułkownikiem z przydziałem do 5 Wileńskiej Brygady Piechoty i w jej szeregach walczył w 2 Korpusie Polskim gen. Władysława Andersa we Włoszech. Zginął w bitwie pod Monte Cassino.

45 Smoliński, Ewakuacja, 70-71. Autor podał m.in., że oba polskie statki „Batory” i „Sobieski" odpłynęły z portu Saint Jean de Luz z ok. 4,5 tys. żołnierzy, w tym z żołnierzami ze Stacji Zbornej w Carpiagne. Na „Batorym” ewakuowali się z Francji generałowie Stanisław Malinowski oraz Tadeusz Kossakowski.

46 Informacje z kalendarzyka Agenda 1940. 
marynarze objaśniali sposób zachowania się w razie groźby zatonięcia statku. Trzymali nas tak długo, aż przepłynęliśmy rejon, w którym pływała oliwa, drewniane skrzynki, deski i różne pozostałości po jakimś statku zatopionym przez niemiecką łódź podwodną.

Pod wieczór 23 czerwca 1940 r. ujrzeliśmy z daleka kołyszące się u brzegów, lśniące balony na uwięzi, stanowiące zaporę dla samolotów. O godzinie 22 przy słonecznym blasku zachodzącego słońca zawinęliśmy z ulgą do angielskiego portu Plymouth. ${ }^{47}$

\section{Bibliografia}

\section{Archiwalia}

Archiwum Instytutu Pamięci Narodowej w Krakowie

Wojewódzki Urząd Spraw Wewnętrznych w Krakowie [1945] 1983-1990

Archiwum Prywatne Rodziny Quirini

Centralne Archiwum Wojskowe Wojskowego Biura Historycznego

Kolekcja Teczek Akt Personalnych

\section{Literatura}

Armia polska i życie społeczne Polaków we Francji. Wrzesień 1939-czerwiec 1940, wybór i oprac. Marian Drozdowski i Józef Smoliński. Warszawa: Typografika, 2001.

Biegański, Witold. Polskie Siły Zbrojne na Zachodzie 1939-1945. Warszawa: Krajowa Agencja Wydawnicza, 1990.

Biegański, Witold. Finał dziwnej wojny. Studium o kampanii francuskiej 1940. Warszawa: Wyd. Ministerstwa Obrony Narodowej, 1970.

Biegański, Witold. Wojsko Polskie we Francji 1939-1940. Warszawa: Wyd. Ministerstwa Obrony Narodowej, 1967.

Biegański, Witold. Zaczęło się w Coëtquitan: $z$ dziejów polskich jednostek regularnych we Francji. Warszawa: Wyd. Ministerstwa Obrony Narodowej, 1977.

Bielak, Monika. „Ewakuacja żołnierzy polskich z Francji do Wielkiej Brytanii i Afryki Północnej w latach 1940-1941." W Letnia Szkoła Historii Najnowszej 2008: Referaty. Red. Monika Bielak i Łukasz Kamiński, 13-19. T. 2. Warszawa: Instytut Pamięci Narodowej, 2009.

Bilek-Dąbrowska, Zofia. „Ligocki Edward.” Polski Stownik Biograficzny 17, (1972): 323-325.

Korczyk, Henryk. „Quirini de Saalbrück Eugeniusz.” Polski Słownik Biograficzny 29, (1986): 532.

Koreś, Daniel. „Antoni Szuszkiewicz (1886-1979).” Polski Słownik Biograficzny 49, z. 3 (2014): 407.

Quirini-Popławska, Danuta. ,[Eugeniusz Quirini de Saalbruck], Kirkcaldy. Polska gwiazdka w Szkocji w 1940 r.” Zeszyty Naukowe UJ, Prace Historyczne 49, z. 3 (2021): 623-639. http://dx.doi.org/10.4467/20844069PH.21.040.14016.

$47 \quad$ Informacje z kalendarzyka Agenda 1940. 
Smoliński, Józef. „Działalność naczelnych władz wojskowych podczas ewakuacji wojska polskiego do Wielkiej Brytanii w czerwcu 1940 r." Niepodlegtość i Pamięć 6, nr 2 (1999): 213-228.

Smoliński, Józef. Ewakuacja Wojska Polskiego do Wielkiej Brytanii w czerwcu 1940. Warszawa: Egros, 1996.

Smoliński, Józef. „Koncepcje formowania i użycia Wojska Polskiego we Francji (wrzesień 1939-czerwiec 1940)." Niepodległość i Pamięć 24, nr 2 (2017): 151-173.

Smoliński, Józef. Polskie Sity Zbrojne na Zachodzie 1939-1945. Warszawa: Egros, 1997.

Smoliński, Józef. „Wysiłek wojenny Polskich Sił Zbrojnych na Zachodzie (19391945)." Niepodległość i Pamięć 26, nr 4 (2019): 91-125.

Szczurowski, Maciej. „Geneza formowania Armii Polskiej we Francji 1939-1940.”

Piotrkowskie Zeszyty Historyczne 4, (2002): 115-143.

Terlecki, Olgierd. Generał Sikorski. T. 1. Kraków: Wyd. Literackie, 1981.

Zuziak, Janusz. „Wysiłek mobilizacyjno-organizacyjny Polskich Sił Zbrojnych na Zachodzie w drugiej wojnie światowej." Piotrkowskie Zeszyty Historyczne 5, (2003): 235-246.

\section{STRESZCZENIE}

\section{Danuta Quirini-Popławska, Eugeniusz Quirini de Saalbrïck, Kartki z działalności żotnierzy polskich we Francji i ich ewakuacja do Wielkiej Brytanii w czerwcu 1940 r.}

Autor wspomnienia 5 września 1939 r. został odkomenderowany do dyspozycji szefa Biura Propagandy Naczelnego Wodza i wraz z rządem 17 września 1939 r. przekroczył granicę w Kutach. W Rumunii był internowany do 26 grudnia 1939 r. 1 stycznia 1940 r. zameldował się w Stacji Zbornej w koszarach Besseries w Paryżu. Mianowany referentem kulturalno-oświatowym w Stacji Zbornej Oficerów w Camp de Carpiagne (koło Marsylii), wykonywał powierzone zadania do 18 czerwca 1940 r. Autor relacjonuje sytuację polityczną we Francji oraz podkreśla pacyfistyczne nastroje społeczeństwa francuskiego. Przedstawia działalność wychowawczo-oświatową w Stacji, umacniającą w polskich żołnierzach wiarę w zwycięstwo nad hitlerowskim najeźdźcą. Omawia postawę nowych władz francuskich, które zdecydowały, że powstałe we Francji Wojsko Polskie winno złożyć broń i oddać się do niewoli niemieckiej. Autor wspomnienia szczegółowo relacjonuje tragiczne i niezmiernie skomplikowane położenie polskiego żołnierza, który mimo kapitulacji Francji chciał dalej się bić. Opisuje ewakuację polskich żołnierzy od 18 do 21 czerwca 1940 r. z Camp de Carpiagne, polskiego szpitala oraz innych uciekinierów do małego portu Saint Jean de Luz położonego przy hiszpańskiej granicy. Po karkołomnych przygodach dotarli do portu, gdzie czekał na nich transatlantyk MS „Batory”, 23 czerwca dopłynęli do angielskiego portu Plymouth.

Słowa kluczowe: Eugeniusz Quirini de Saalbrück, Wojsko Polskie we Francji (1939-1940), kampania francuska 1940 r., Camp de Carpiagne, ewakuacja 


\section{SUMMARY}

\section{Danuta Quirini-Popławska, Eugeniusz Quirini de Saalbrück, Cards regarding the activities of Polish soldiers in France and their evacuation to Great Britain in June 1940}

On September 5, 1939, the author of the memoirs was delegated to the Head of the Propaganda Bureau of the Polish Commander-in-Chief and, together with the government, on September 17, 1939, crossed the border at Kuty. In Romania, he was interned until December 26, 1939. On January 1, 1940, he reported to the Assembly Station in the Besseries barracks in Paris. Appointed as a cultural and educational clerk at the Officers' Assembly Station in Camp de Carpiagne (near Marseilles), he performed his assigned tasks until June 18, 1940. The author reports on the political situation in France and emphasizes the pacifist mood of French society. He presents educational activities at the Station, strengthening the faith in Polish soldiers in the victory over the Nazi invader. He discusses the attitude of the new French authorities, which decided that the Polish Army established in France should lay down their arms and surrender to the Germans. The author gives a detailed account of the tragic and extremely complicated situation of a Polish soldier who, despite France's capitulation, wanted to continue fighting. He describes the evacuation of Polish soldiers from 18 to 21 June 1940 from Camp de Carpiagne, a Polish hospital and other refugees, to the small port of Saint Jean de Luz on the Spanish border. After a series of adventures, they reached the port where the ocean liner Batory was waiting, and on June 23 they sailed to the English port of Plymouth.

Keywords: Eugeniusz Quirini de Saalbrück, Polish Army in France (19391940), French Campaign 1940, Camp de Carpiagne, evacuation

\section{АННОТАЦИЯ}

\section{Данута Квирини-Поплавска, Эугениуш Квирини де Заальбрюк, О деятельности польских солдат во Франиии и их эвакуации в Великобританию в июне 19402.}

Автор «Воспоминаний» 5 сентября 1939 г. был делегирован к начальнику Бюро пропаганды Польского Главнокомандующего и 17 сентября 1939 г. вместе с правительством пересек границу в Кутах. В Румынии он был интернирован до 26 декабря 1939 г. 1 января 1940 г. он явился на Сборочную станцию в казармах Бессери в Париже. Назначенный референтом по вопросам культуры и образования на Сборочной станции офицеров в Кампде-Карпьян (недалеко от Марселя), он выполнял поставленные ему задачи до 18 июня 1940 г. Автор сообщает о политической ситуации во Франции и подчеркивает пацифистские настроения французского общества, а также описывает просветительскую деятельность на Станции, укрепляющую веру 
польских солдат в победу над гитлеровскими захватчиками. Он обговаривает позицию новых французских властей, которые решили, что польская армия, расположенная во Франции, должна сложить оружие и сдаться немецкому плену. Автор «Воспоминаний» подробно описывает трагическое и чрезвычайно сложное положение польского солдата, который, несмотря на капитуляцию Франции, хотел продолжить сражение. Кроме того, автор описывает эвакуацию польских солдат с 18 по 21 июня 1940 г. из Камп-де-Карпьян, из польского военного госпиталя, а также других беженцев, в небольшой порт Сен-Жан-де-Люз, расположенный на испанской границе. После различных приключений они достигли порта, где их ждал океанский лайнер «Баторий», и 23 июня они отплыли в английский порт Плимут.

Ключевые слова: Эугениуш Квирини де Заальбрюк, Польская армия во Франции (1939-1940), Французская кампания 1940 года, Камп-де-Карпьянь, эвакуация 